Received $28^{\text {th }}$ November 2017,

Accepted $22^{\text {th }}$ January 2018

Link to DOI:

10.25220/WNJ/V01.i2.0008

Journal Website: www.worldnutrijournal.org

\section{Macronutrient Intake and Life Style Factors Associated to HbA1c Status in Type-2 Diabetic Patients}

\author{
Imelda Wiradarma, ${ }^{1}$ Saptawati Bardosono, ${ }^{1}$ Soeharko Soebardi, ${ }^{3}$ \\ 1. Department of Nutrition Medical Faculty Universitas Indonesia - Cipto Mangungkusumo General \\ Hospital \\ 2. Department of Internal Medicine, Faculty of Medicine Universitas Indonesia - Cipto \\ Mangunkusumo General Hospital
}

\begin{abstract}
Background: This study aims to determine the relationship between macronutrients intake and lifestyle factors to HbA1c status of type-2 diabetic patients in improving the effectiveness of patient's nutritional support therapy and preventing diabetic complications.

Methods: Type-2 diabetic patients were categorized into 2 groups, i.e. patients with good glycemic control with $\mathrm{HbA} 1 \mathrm{c}<7.0$ and patients with poor glycemic control with $\mathrm{HbA} 1 \mathrm{c} \geq 7.0$. Data collection included clinical characteristics (i.e. age, gender, body mass index, duration of illness, type and amount of diabetic medication, and diabetic complication). Macronutrient intake consisted of total daily calories and carbohydrate, protein, fat and fiber intakes, whilelifestyle factors consisted of the adherence to dietary advice and medication, physical activities, smoking habit, and alcohol intake. The relationships between all data to HbA1c status were analyzed using Chi Square test.

Results: Younger type-2diabetic patients ( $<55$ years old), carbohydrate intake, and adherence to dietary advice had statistically significant in related to HbA1c status $(p<0.05)$.

Conclusions: Health and nutrition education should be provided to the younger age of type2diabetic patients to maintain proper dietary pattern following to medical nutrition therapy.
\end{abstract}

Keywords HbA1c status, lifestyle, macronutrient intake

\section{Introduction}

Approximately $90 \%$ of worldwide Diabetes Mellitus (DM) patients are havingtype-2 Diabetes Mellitus (T2DM). Diabetes Mellitus has become an epidemic in recent years. In year 2000, around 150 millions people in the world suffered from DM, and it was estimated to reach 300 millions in the

\footnotetext{
Corresponding author:

Imelda Wiradarma

Department of Nutrition Medical Faculty, Universitas Indonesia - Cipto Mangunkusumo General Hospital

Email address : wiradarma.imelda@yahoo.co.id
}

year 2025. Developing countries in Asia, South America, and Africa are expected to have the biggest increase in T2DM patients. ${ }^{1,2}$ Based on data from Health Research and Development of Indonesia Ministry of Health the prevalence of T2DM patients and impaired glucose tolerant patients in Indonesia in 2008 is $5.7 \%$ and $10.25 \%$, respectively. By 2020, the prevalence of T2DM patients in Indonesia is estimated to be 8.2 millions of 178 millions citizen with age above 20 years old. $^{3}$

Numerous extensive clinical studies demonstrate that strict control of blood glucose level correlates with the reduction of micro- 
vascular complication risk. American Diabetes Association (ADA) and American Association of Clinical Endocrinologist (AACE) have set a target of $\mathrm{HbA} 1 \mathrm{c}$ less than $6.5 \%$ as the optimum glycemic control. Despite the evidence of various studies which reveal the benefits of intensive treatment to reduce the risk of micro- and macro-vascular complications for diabetic patients, the number of patients with poor glycemic control remains high. T2DM patients with poor glycemic control are becoming apublic health issue because they have higher risk to develop diabetes complications in the future. ${ }^{4,5}$ For Indonesian, the Indonesian Society of Endocrinologist (Perkumpulan Endokrinologi Indonesia/ PERKENI) has set a target for $\mathrm{HbA1c}$ less than $7.0 \%$ as the optimum glycemic control. ${ }^{6}$

Glycemic control is still one of the therapeutic target to prevent major organ damage and other complications for DM patients. During clinical treatment, it is difficult to reach optimum glycemic level in a long-term basis for T2DM patients due to complex reasons. The main reason for poor glycemic control is DM patients' low understanding on the long-term dietary benefits. Results from cross-sectional studies indicate low compliance to dietary recommendation which includes macronutrient intake and fruit and vegetable consumption. ${ }^{7} \mathrm{Hu}$ et $\mathrm{al}^{8}$ followed 84.941 female nurses between year 1980 and 1996 (The Nurses' Health Study) and concluded that obesity was the major important predictor of diabetes, while lack of exercises, poor diet, smoking habit, and alcohol intake were also associated with the risk increase in developing diabetes. Rawal et $\mathrm{al}^{9}$ examined nine publications about the prevention of T2DM and its complications which were conducted in developing countries. The studies concluded that non-pharmacological intervention and lifestyle change were found to be effective in reducing the risk of developing T2DM in patients with impaired glucose tolerance and improving the glycemic control of T2DM patients. This study was done to determine the relationship between macronutrient intake and lifestyle factors to HbA1c status of type2 diabetic patients who attended Diabetes Clinic in Husada Hospital Jakarta, Indonesia.

\section{Methods}

This is a cross sectional study that recruited type- 2 diabetic patients who attended Diabetes Clinic in Husada Hospital Jakarta between April to May 2015 by consecutive sampling. The eligibility criteria including over 18 years old, male or female T2DM patients who had medical nutrient therapy for minimum three months, and willing to participate in the study. Patients who were pregnant, breastfeeding mother, had moderate or severe anemia, and/or unable to stand or walk were excluded. All subjects had given informed consent to participate in the study. Sample size was determined by using rule of thumb in analyzing difference in two proportions by having a minimal total sample of 40 subjects.

Approval from the Ethics Committee of Faculty Medicine of University of Indonesia was released before conducting the data collection. Individual interview was held to collect age, gender, the duration of illness, type and amount of diabetic medications, other diabetic complications, and physical activities data. Macronutrient intake pattern (total daily calories and carbohydrate, protein, fat and fiber intake) of at least 1 month were analyzed using semi-quantitative Food Frequency Questionnaire (FFQ). Lifestyle data were collected to assess the adherence to medicine intake, smoking habit, and alcohol intake using $1 \mathrm{x}$ 24-hour food recall. Food intake information was disaggregated, converted, and averaged into daily nutrient intake using a computer analysis program called Nutrisurvey 2007. Body mass index (BMI) was calculated as weight in kilograms (SECA scale) divided by the square of height in meters (Microtoise stature meter), the result was then categorized according to Asia-Pacific BMI classification. Glycemic control of $\mathrm{HbA1c}$ was analyzed using high performance liquid chromatography, D-10, and the hemoglobin using flow-cytometry (Sysmex).

All statistical analyses were performed using SPSS software package version 20 program. All categorical data were presented as proportions. Chi Square test was used to examine the relationship between macronutrient composition intake and lifestyle factors to HbA1c status. A pvalue of $<0.05$ was considered as statistically significant. 


\section{Results:}

\section{Clinical Characteristics}

This study included 57 T2DM patients whose age between 40 to 79 years old, with median age of 55 years old, median BMI of $26.9 \mathrm{~kg} / \mathrm{m} 2$ (19.0-45.4), median duration of illness of 5 years (1-30 years), and mean (SD) of haemoglobin of $12.8 \pm 1.3 \mathrm{~g} / \mathrm{dl}$.

Among all clinical characteristics variables studied, i.e. age, gender, BMI, duration of illness, type and amount of diabetic medication consumed, and other diabetic complications, only age was significantly related to $\mathrm{HbAlc}$ ( $\mathrm{p}$-value $=0.012$, see Table 1). This study shows that subjects less than 55 years old had a significantly poor glycemic control $(\mathrm{Hb} 1 \mathrm{Ac} \geq 7.0)$ compared to those among older age.

\section{Macronutrient intake}

Table 2 shows that approximately $10 \%$ of the subjects had high daily calorie intake compared to the PERKENI recommendation. This condition can be related to the high proportion of subjects had high fat intake. However, only carbohydrate intake that significantly associated to $\mathrm{HbAlc}$ status, in which high carbohydrate intake was only found among those with poor glycemic control (pvalue $=0.032$ ). PERKENI macronutrient ratio recommendation are carbohydrate $45-65 \%$, protein $10-20 \%$, and lipid $20-25 \% 6$.

Table 1 Clinical characteristics of study subjects and HbA1c status

\begin{tabular}{|c|c|c|c|c|}
\hline \multirow[t]{2}{*}{ Clinical Characteristics } & \multirow[t]{2}{*}{ Frequency $(\%)$} & \multicolumn{2}{|l|}{ HbA1c status } & \multirow{2}{*}{$\begin{array}{l}\text { P-value } \\
\text { (chi-square test) }\end{array}$} \\
\hline & & $<7.0(\mathrm{n}=26)$ & $\geq 7.0(\mathrm{n}=31)$ & \\
\hline \multicolumn{5}{|l|}{ Age, years } \\
\hline $18-55$ & $29(50.8)$ & 8 & 21 & 0.012 \\
\hline$>55$ & $28(49.2)$ & 18 & 10 & \\
\hline \multicolumn{5}{|l|}{ Gender } \\
\hline Male & $11(19.3)$ & 6 & 5 & 0.745 \\
\hline Female & 46 (80.7) & 20 & 26 & \\
\hline \multicolumn{5}{|l|}{ BMI, $\mathrm{kg} / \mathrm{m}^{2}$} \\
\hline$<18.5$ & - & - & - & \\
\hline $18.5-22.9$ & $11(19.3)$ & 4 & 7 & 0.727 \\
\hline $23-24.9$ & 14 (24.6) & 8 & 6 & \\
\hline $25-29.9$ & $15(26.3)$ & 9 & 6 & \\
\hline$\geq 30$ & $17(29.8)$ & 5 & 12 & \\
\hline \multicolumn{5}{|l|}{ Duration of diabetes } \\
\hline$<5$ & $28(49.2)$ & 16 & 12 & 0.147 \\
\hline$\geq 5$ & $29(50.8)$ & 10 & 19 & \\
\hline \multicolumn{5}{|l|}{ Diabetes treatment } \\
\hline None & $3(5.3)$ & 3 & - & 0.792 \\
\hline $\mathrm{OHO}$ & $49(85,9)$ & 21 & 28 & \\
\hline Insulin & $3(5.3)$ & 1 & 2 & \\
\hline Combination & $2(3.5$ & 1 & 1 & \\
\hline \multicolumn{5}{|c|}{ Amount of diabetic medicine } \\
\hline None & $3(5.3)$ & 3 & - & 0.169 \\
\hline 1 & $21(36.8)$ & 11 & 10 & \\
\hline$>1$ & $33(57.9)$ & 12 & 21 & \\
\hline \multicolumn{5}{|l|}{ Diabetic complication } \\
\hline None & $6(10.5)$ & 3 & 3 & 0.576 \\
\hline Yes & $51(89.5)$ & 23 & 28 & \\
\hline
\end{tabular}


Table 2 Macronutrient intake of study subject and $\mathrm{HbA} 1 \mathrm{c}$ status

\begin{tabular}{|c|c|c|c|c|}
\hline \multirow[t]{2}{*}{ Macronutrient intake } & \multirow[t]{2}{*}{ Frequency (\%) } & \multicolumn{2}{|l|}{ HbAlc status } & \multirow{2}{*}{$\begin{array}{l}\text { P value } \\
\text { (chi-square test) }\end{array}$} \\
\hline & & $<7.0(\mathrm{n}=26)$ & $\geq 7.0(\mathrm{n}=31)$ & \\
\hline \multicolumn{5}{|c|}{$\begin{array}{l}\text { Daily calorie intake, \% the } \\
\text { recommendation }\end{array}$} \\
\hline$<90$ & $26(45.6)$ & 11 & 15 & \multirow[t]{3}{*}{0.523} \\
\hline $90-110$ & $25(43.8)$ & 13 & 12 & \\
\hline$>110$ & $6(10.6)$ & 2 & 4 & \\
\hline \multicolumn{5}{|c|}{$\begin{array}{l}\text { Carbohydrate }(\mathrm{C}), \% \text { total } \\
\text { calorie }\end{array}$} \\
\hline$<45$ & $15(26.3)$ & 8 & 6 & \multirow{3}{*}{0.032} \\
\hline $45-60$ & $37(64.9)$ & 18 & 20 & \\
\hline$>60$ & $5(8.8)$ & - & 5 & \\
\hline \multicolumn{5}{|c|}{ Protein $(\mathrm{P}), \%$ total calorie } \\
\hline$<10$ & - & - & - & \multirow[t]{3}{*}{0.499} \\
\hline $10-20$ & $52(91.2)$ & 23 & 29 & \\
\hline$>20$ & $5(8.8)$ & 3 & 2 & \\
\hline \multicolumn{5}{|l|}{ Fat $(\mathrm{F}), \%$ total calorie } \\
\hline$<20$ & $1(1.8)$ & - & 1 & \multirow[t]{3}{*}{0.103} \\
\hline $20-25$ & $2(3.5)$ & - & 2 & \\
\hline$>25$ & $54(94.7)$ & 26 & 28 & \\
\hline \multicolumn{4}{|l|}{ Fiber, $\mathrm{g}$} & \multirow{4}{*}{0.187} \\
\hline$<20$ & $2(3.5)$ & - & 2 & \\
\hline $20-25$ & $21(36.8)$ & 7 & 14 & \\
\hline$>25$ & $34(59.7)$ & 19 & 15 & \\
\hline \multirow{2}{*}{\multicolumn{5}{|c|}{$\mathrm{C}, \mathrm{P}, \mathrm{F}$ ratio, $\%$ total calorie }} \\
\hline & & $47: 18: 35$ & $51: 16: 33$ & \\
\hline
\end{tabular}

\section{Lifestyle}

Approximately 54.4\% subjects had good adherence to dietary advice and performed light activities, while $86 \%$ subjects had good adherence to medication, only $7 \%$ were active smokers, and none were consuming alcohol.
Physical activity categories were based on Compedium of Physical Activities (light MET $<3$, moderate MET 3-6, heavy MET>6). ${ }^{10}$ Table 3 shows a significant relationship between adherence to diet and HbAlc status ( $p$-value $=0.004$ ), in which those not adhered to diet had higher proportion of poor glycemic control.

Table 3 Life style of study subjects and HbA1c status

\begin{tabular}{cllll}
\hline Life style Characteristics & Frequency $(\%)$ & \multicolumn{2}{c}{ HbA1c status } & P value \\
\cline { 3 - 4 } (chi-square test)
\end{tabular}

MET: metabolic equivalent 


\section{Discussions}

This study shows that age, carbohydrate intake and adherence to diet had significant relationships to HbAlc status of type- 2 diabetic patients in Diabetes Clinic of Husada Hospital Jakarta. By age category, Karakelides, ${ }^{11}$ stated that there is agerelated decline in insulin sensitivity which is secondary to age-related changes in body composition (central obesity); and that a longer duration of $\mathrm{DM}$ is related to the increase in insulin resistance. $^{5}$ Longer duration of the disease will reduce insulin endogen, thus T2DM patients would need multiple medicines to control their blood glucose level. ${ }^{12}$ Woo $^{13}$ stated that higher intake of protein, lipid, zinc, and vitamin E affected good glycaemic control significantly, and macronutrient composition intake in elder diabetic patient was better in good glycemic (60:20:20) compared to poor glycaemic control patients $(71: 15: 15)$.

Most diabetic patients were reducing their carbohydrate-sourced foods in order to lower their total daily calorie intake. This study shows that although there was no statistically significant relationships between protein, fat, and fiber intake to HbAlc status, subjects who had high carbohydrate intake significantly had poor glycemic control. This is in accordance to the fact that medical nutrition therapy is necessary in preventing diabetes, managing existing diabetes, and preventing or delaying the rate of developing diabetes complications. ${ }^{14}$ In addition to macronutrients intake, adherence to diet had statistically significant relationship to $\mathrm{HbAlc}$ status.

\section{Study Limitation}

This study had recall bias threat in duration of diabetes and disease complications, because the data recorded were from patients' self-report without further validation from physical examination and laboratory finding.

\section{Conclusion}

In conclusion, younger type- 2 diabetic patients (age $<55$ year old) and patients with $\mathrm{HbAlc}$ level $\geq 7.0 \%$ are recommended to be well informed about their diet, especially with regards to type of macronutrient-rich foods.

\section{Conflict of Interest}

Authors declared no conflict of interest regarding this study.

\section{Open Access}

This article is distributed under the terms of the Creative Commons Attribution 4.0 International Liscense (http://creativecommons.org/licenses/by/4.0/), which permits unrestricted use, distribution, and reproduction in any medium, provided you give appropriate credit to the original author(s) and the source, provide a link to the Creative Commons license, and indicate if changes were made.

\section{Acknowledgement}

We would like to acknowledge all staff of Poliklinik Onkologi 1 and Instalasi Gizi of Dharmais Cancer Hospital who had helped this study.

\section{References}

1. Suyono S. Diabetes melitus di Indonesia. Dalam: Sudoyo AW, Setiyohadi B, Alwi I, Simadibrata M, Setiati S, editor. Buku Ajar Ilmu Penyakit Dalam. Jakarta: Interna Publishing; 2009. [Google Scholar]

2. Hermansen MLF, Eriksen NMB, Mortensen LS, Holm L, Hermansen K. Can the glycemic index (GI) be used as a tool in the prevention and management of type 2 diabetes. Rev Diabetic Stud 2006;3:61. [Google Scholar]

3. Suyono S. Kecenderungan peningkatan jumlah penyandang diabetes. In: Soegondo S, Soewondo P, Subekti I. Penatalaksanaan Diabetes Melitus Terpadu. Jakarta: Fakultas Kedokteran Universitas Indonesia; 2009. [Google Scholar] 
4. Waspadji S. Komplikasi kronik diabetes: Mekanisme terjadinya, diagnosis dan strategi pengelolaan. In: Sudoyo AW, Setiyohadi B, Alwi I, Simadibrata M, Setiati S, editor. Buku Ajar IlmuPenyakitDalam. Jakarta: Interna Publishing; 2009. [Google Scholar]

5. Khattab M, Khader YS, Al-Khawaldeh A, Ajlouni K. Factors associated with poor glycemic control among patients with type 2 diabetes. Journal of Diabetes and Its Complications 2010;24:84. [Google Scholar]

6. Perkumpulan Endokrinologi Indonesia. Konsensus pengendalian dan pencegahan diabetes melitustipe 2 di Indonesia. 2011

7. Yannakoulia M. Eating behaviour among type 2 diabetic patients: a poorly recognized aspect in a poorly controlled disease. Rev Diabetic Stud 2006;3:11. [Google Scholar]

8. Hu FB, Manson JE, Stampfer MJ, Colditz G, Liu S, Solomon CG, et al. Diet, lifestyle, and the risk of type 2 diabetes mellitus in women. New England journal of medicine 2001 Sep;345(11):790-7. [Google Scholar]

9. Rawal LB, Tabb RJ, Williams ED, Chan C, Yasin S, Oldenburg B. Prevention of type 2 diabetes and its complications in developing countries: a riview. Int J Behav Med 2012;19:121. [Google Scholar]

10. Ainsworth BE, Haskell WL, Whitt MC, Irwin ML, Swartz AM, Strath SJ, et al. Compendium of physical activities: an update of activity codes and MET intensities. Medicine \& Science in Sports \& Exercise 2000;32. [Google Scholar]

11. Karakelides H, Irving BA, Short KR, O'Brien P, Nair KS. Age, obesity, and sex effects on insulin sensitivity and skeletal muscle mitochondrial function. Diabetes 2010;59:89. [Google Scholar]

12. Donelly LA, Morris AD, Evans JM. Adherence to insulin and its association with glycaemic control in patient with type 2 diabetes. Quarterly Journal of Medicine 2007; 100:345. [Google Scholar]

13. Woo MH, Park S, Woo JT, Choue R. A comparative study of diet in good and poor glycemic control groups in elderly patients with type 2 diabetes mellitus. Korean Diabetes J 2010;34:303. [Google Scholar]

14. Franz MJ. Medical nutrition therapy for diabetes mellitus and hypoglycemia of nondiabetic origin. In: Mahan LK, EscottStump S, Raymond JL, editor. Krause's Food and the Nutrition Care Process. $13^{\text {th }}$ ed. Missouri: Elsevier Saunders, 2012:675-710. 